It is felt in some quarters that a school of fishing should be established in Great Britain, particularly for the training of fishery officers and others who will be going out to British Colonies under the Colonial Development Scheme. It is doubtful whether there would be enough trainees derived from this source to support a satisfactory school on a permanent basis. But the British fishing industry also would benefit if the recruits to its ranks could have a period of training in a well-planned and wisely conducted school of fisheries such as that at Cronulla. Fishing in Britain and other European countries has long ceased to be run on primitive 'rule-of-thumb' lines, and there seems at present to be a decided danger that British fishermen may be outstripped by Continental rivals who give more attention to the proper study of fishing in all its aspects.

G. A. Steven

\section{BOTTOM DEPOSITS OF LAKE WINDERMERE IN RELATION TO THE QUATERNARY HISTORY OF THE BRITISH ISLES}

\footnotetext{
$\mathrm{T}$
}

HE importance of the bottom deposits of Lake

Windermere as a source of information concerning the post-glacial history of north-westerm England has already been indicated by the stratigraphy and diatom sequence established by Winifred Pennington (Mrs. T. G. Tutin) (New Phytol., 42, 1 ; 1943). These deep-water deposits (brought within reach by the unique qualities of the Jenkin coresampler) have been used again by the same worker to extend our knowledge into the late-glacial period (Phil. Trans. Roy. Soc., B, 233, 137 ; 1947). Waterlaid, laminated clays are found above and below a layer of grey detritus silt which contains remains indicating that it was laid down during a cooltemperate phase. This is tentatively correlated with the Allerød oscillation established in north-westerm Europe and Ireland.

Analysis of the post-glacial layers (utilizing both pollen and macroscopical plant remains) reveals a fairly close correlation with events in East Anglia, except in the later stages where a Salix maximum occurs in Zone IV and Betula assumes, in Zone V and early Zone VI, the dominance characteristic of profiles from the west of Britain. Tilia does not appear until Zone VII, and Fagus and Carpinus are completely absent. Pinus, which appears to be consistently over-represented in the deep-water deposits, falls off very rapidly at the transition between Zones VIc and VII, but always reappears at a characteristic position near the surface, where the brown and indurated clay gives way to soft, black, rather unconsolidated gyttja. This reappearance may be due to planting (a rise in the importance of grass pollen in deposits laid down 2,000-2,500 years ago having already suggested the beginning of clearance of the primeval forests).

Samples from beneath shallow water provided the clearest pictures of the late-glacial and early postglacial changes, but deposition appears to have ceased (due to turbulence) when the mud has approached to within about three metres of the water-surface. The lesser clarity of the early stages of deep-water samples appears to be due to a very slow deposition here.
Possible correlations of dating with geological reports for north-western England, Ireland and Scandinavia are clearly shown in tabular form, and it is concluded that the lower laminated clay is contemporaneous with the Scottish re-advance, the Carlingford re-advance in Ireland and the Lower Dryas clay in Denmark, and its end is placed at about 10,000 B.c. The commencement of the deposition of the upper laminated clay is placed at 8,300 B.c., and its continuation for some four to five hundred years (estimated by counting the varves) is believed to be the result of a valley glaciation in the Lake District. This is correlated with the Antrim coast re-advance and valley glaciation in the Wicklow Mountains, the Upper Dryas clay of Denmark and the formation of the great Fenno-Scandian moraines. In the post-glacial period, a dating between 6,300 and 6,000 B.c. for the Boreal-Atlantic transition also agrees with Scandinavian results.

A brief correlation with the previous work is made and the greater detail revealed by pollen-analysis is demonstrated, while the same technique is also made to shed further light on the stratigraphical results previously obtained.

H. G. BAKER

\section{THE NORWEGIAN POLAR INSTITUTE}

$O^{N}$ March 1, the Norwegian Polar Institute (Norsk Polarinstitutt) was established in Oslo in order to continue and expand the activity of Norges Svalbard- og Ishavs-undersøkelser. The latter office was founded in 1928, when it took over the work which since 1909 had been carried out by Government-supported expeditions to Svalbard. Norges Svalbard- og Ishavs-undersøkelser has been engaged in the preparation of topographic maps and hydrographic charts of the Svalbard region and in geological investigation on Svalbard. It has provided facilities for numerous scientific workers to visit Svalbard and Eastern Greenland, and has carried out a large amount of practical work such as the estah. lishment of aids for navigation and maintenance of weather stations.

Besides continuing this work, the Polar Institute will broaden the scope of the scientific activity, partly by adding specialists of its own permanent staff, and partly by securing the collaboration of specialists who are connected with university institutions in Oslo and Bergen and other scientific organisations. The sphere of interest will be expanded to include the regions of the Antarctic over which Norway claims sovereignty. It is hoped that the Polar Institute will be able to undertake, sponsor or stimulate geological and palæontological research, glaciological and meteorological studies as well as work in the fields of zoology and botany. The publications of Norges Svalbard. og Ishavs-undersøkelser (Skrifter and Meddelelser) will be continued from the Polar Institute without any break in the numbering.

The Polar Institute will not absorb organisations which are primarily engaged in scientific work in the polar regions, such as the Aurora Observatory at Tromsö or the Government Institute of Whaling Research in Oslo; wherever desirable, it will collaborate with these organisations.

The Polar Institute comes under the Department of Industry of the Norwegian Government, but Dr. H. U. Sverdrup, who has been appointed director, 
has also been attached to the University in Oslo. $\mathrm{He}$ will be able to accept special students at the Institute and thus to attract the attention of young men to the problems of the polar regions. Dr. Sverdrup, until this year professor of oceanography in the University of Califormia and director of the Scripps Institute, has himself had a distinguished career as arctic explorer, oceanographer and mathematician. $\mathrm{He}$ is perhaps best known for his observations of the tidal currents over the Siberian Shelf made during the Norwegian expedition of the Maud, and for his two recent books - the part dealing with physical oceanography in "The Oceans" and his "Oceanography for Meteorologists", of which an edition has been published in Britain. He has taken an active and leading part in modern oceanographical research.

\section{FORTHCOMING EVENTS}

(Meeting marked with an asterisk * is open to the public)

Monday, June 21

ROXAL GEOGRAPHICAL SOCIETX (at Kensington Gore, London, S.W.7), at 8.30 p.m.-Dr. Isaiah Bowman: "The Geographical Relation of the U.S.A. to World Policies".

Monday, June 21 -Friday, July 2

Royal Sochetx (at Burlington House, Piccadilly, London, W.1).Conference on "Scientific Information Services".

\section{Tuesday, June 22}

Royal ANTHRopological INSTitute (joint meeting with the INTERNATIONAL AFRICAN INSTITUTE, at 21 Bedford Square, London, W.C.1), at 5 p.m.-Dr. K. L. Little: "The Secret Society as an Arbiter of Culture" (Discussion Meeting).

Wednesday, June 23-Friday, June 25

INSTITUTION OF THE RUBBER INDUSTRY (at Central Hall, Westminster, London, S.W.1). - Rubber Technology Conference.

\section{Thursday, June 24}

ROXal Soctery (at Burlington House, Piccadilly, London, W.1), at 4.30 p.m.-Sir George Thomson, F.R.S.: "Nuclear Explosions" (Bakerian Lecture)

Mineralogical Societr (at the Geological Society, Burlington House, Piccadilly, London, W.1), at 5 p.m.-Scientiflc Papers.

Thursday, June 24-Friday, June 25

Genetical Society of Great Britain (joint meeting with the BRITISH GMPIRE CANCER CAMPAIGN, at the Royal Society of Medicine, 1 Wimpole Street, London, W.1).- Symposium on "The Genetics of Cancer"** (Afternoon Session on Thursday afternoon, at 2.30 p.m.,
at the Medical Society of London, 11 Chandos Street, London, W.1.)

\section{APPOINTMENTS VACANT}

APPUICATIONS are invited for the following appointments on or before the dates mentioned :

DIRECTOR OF THE RESEARCH INSTITUTE OF LAUNDERERS, DRYCLEANERS AND DYERS OF NEW ZEALAND-The Scientifle Adviser, New Zealand Scientific Office, B.C.S.O., Africa House, Kingsway, London, W.C.2 (June 23).

READERSHIP IN BIOCHEMISTRY at University College-The Academic Registrar, University of London, Senate House, London, W.C.1 (June 23).

Assistant in the Department of Physiologt, a Lecturer in CLINICAL CHEMISTRY, and a LECTURER IN THE DEPARTMENT OF Physrolooy - The Secretary, The University, Aberdeen (June 25). LECTURERS (3) IN THE CHEMISTRY DEPARTMENT, LECTURERS (2) IN THE PHYSICS DEPARTMENT, and a LECTURER IN THE CHEMICAL ENGINEERING DEPARTMENT-The Clerk to the Governing Body, Battersea Polytechnic, Battersea, London, S.W.11 (June 26).

SENIOR LeCTURER IN MATHRMatics-The Clerk to the Governors, Chelsea Polytechnic, Manresa Road, London, S.W.3 (June 26).

LeCTURERS (2) IN GEOLOGX-The Registrar, King's College, Newcastle-upon-Tyne (June 26).

assistant Examiners in the Patent OFFice under the Board of Trade-The Secretary, Civil Service Commission, Burlington Gardens, London, W.1, quoting No. 45A (June 30).

GRASSLAND AGRONOMIST, and a PLANT BREEDER with training in mycology-The Director, Welsh Plant Breeding Station, Agricultural Research Building, Penglais, Aberystwyth (June 30).

LECTURER IN BOTANY in the United College, St. Andrews-The Secretary, The University, St. Andrews (June 30).

TUTORIAL RESEARCH STUDENTSHIP IN MATHEMATICS (Pure or Applied)-The Principal, Royal Holloway College, Englefield Green, Surrey (June 30).
ASSISTANT LECTURER or LECTURER IN GEOLOGY -The Secretary, The University, Aberdeen (June 30).

Lenersity The Secretary, Universities Bureau of the British Empire, 8 Park Street, London, W.1 (June 30).

PATENT OFFICERS under the Ministry of Supply-The Secretary, Civil Service Commission, 6 Burlington Gardens, London, W.1, quoting No. 2175 (June 30 )

Research Frllowships in Mathomatical Physics-The Secretary, The University, Edmund Street, Birmingham 1 (July 1).

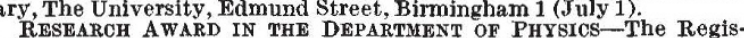
trar, University College, Hull (July 2).

RESEARCH OFFTOER IN THE DIVISION OF INDUSTRIAL CHEMISTRY for the investigation of relationships between the molecular structure and dielectric properties of electrical insulating materials-The Secretary, Australian Scientific Research Liaison Office, Africa House, Kingsway, London, W.C.2, quoting No. 1701 (July 3).

COUNTY HORTICULTURAL INSTRUCTOR (male) on the staff of the Somerset Farm Institute, Cannington, Bridgwater-The Chief Education Officer, County Hall, Taunton (July 3).

HEAD OF THE DEPARTMENT OF AGRICULTURe, HFAD OF THE DEPARTMENT OF VETERINARY SCIENCE, and a HEAD OF THE DEPARTMENT OF FORESTRY, at University College, Ihadan, Nigeria-The Secretary, Inter-University Council for Higher Education in the Colonies, 8 Park Street, London, W.1 (July 3).

PROFESSORSHIPS OF PHARMACOLOGY, ENTOMOLOGY, PRotozoology, and PATHOLOGY and BACTERIOLOGY, at the School of Tropical Medicine, Calcutta-The High Commissioner for India, General Department, India House, Aldwych, London, W.C.2, quoting No. 4/26A (July 5) LECTURER IN THE DEPARTMENT OF BOTANY, University of Cape Town-The Secretary, Universities Bureau of the British Empire, 8 Park Street, London, W.1 (Cape Town, July 15).

Professor OF CIVIL ENGINEERING CONSTRdOTION AND FOUNDATIONS, a PROFESSOR OF STRENGTH OF MATERIALS, a PROFESSOR OF HYDRAULIOS AND WATER POWER, a PROFESSOR OF STIEL BRIDGeS

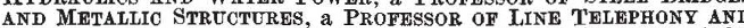
TRLEgRAPHY, and a PROFESSOR OF ELECTRIC POWER STATIONS, at the Farouk I University, Alexandria-The Director, Egyptian Education Bureau, 4 Chesterfleld Gardens, London, W.1 (July 15).

CHALuIs ChaIR of HISTORY in the University of Sydney-The Secretary, Universities Bureau of the British Empire, 8 Park Street, London, W.1 (July 31).

Professor of Mathrimatios and Head of The DePartment, and a PROFEssor of Mathematical Physics, in the University of Cape Town-The Secretary, Universities Bureau of the British Empire, 8 Park Street, London, W.1 (July 31 ).

CHATR OF ELECTRICAL ENGIV University of SydneyThe Secretary, Universities Bureau of the British Empire, 8 Park Street, London, W.1 (Sydney, August 15).

LECTURER IN MATHEMATICS--The Registrar, The University, Read-

ing. LECTURER IN APPLIED MECHANICS, at the Roval Naval College, Greenwich-The Director (P.A.), Education Department, Admiralty, Greenwich-The

RESEARCH STATISTICIANS and Assistant Statisticians-The RESEARCH STATISTICIANS and ASSISTANT STATISTICIANS-Th
Secretary, Rothamsted Experimental Station, Harpenden, Herts. Secretary, Rothamsted Experimental Station, Harpenden, Herts.
LECTURER IN BOTANY, and a LECTURER IN ECONOMIC, at the LECTURER IN BOTANY, and a LECTURER IN ECONOMICS, at the
Imperial College of Tropical Agriculture, Trinidad-The Secretary, Imperial College of Tropical Agriculture, Trinidad--The Secretary, Square, London, W.C.2

quare, London, W.C.2. LABORATORY ASSISTANT with experience of chemical and/or biochemical analysis-The Department of Veterinary Hygiene an

ventive Medicine, Royal (Dick) Veterinary College, Edinburgh. SENIOR LECTURRR and LECTURRR IN PHYSICS in the University of
Otago, Dunedin-The High Commissioner for New Zealand, 415 Strand, London, W.C.2

PHYsIcIST, and and Allied Feltmakers' Research Association, Department of Textile Industries, The University, Leeds 2.

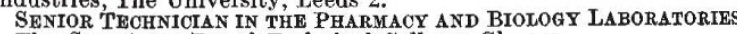
-The Secretary, Royal Technical College, Glasgow.

\section{REPORTS and other PUBLICATIONS (not included in the monthly Books Supplement)}

\section{Great Britain and Ireland}

Society for Psychical Research: an Outline of its History. By W. H. Salter. Pp. 54. (London: Society for Psychical Research 1948.) 28. Family Planning Association. Conference on Infertility held at the Nuffield Institute for Medical Research, Oxford, July 26 and 27 58.6d. Pp. 64. (London: Family Planning Association, 1948.

\section{Other Countries}

University of Cllinois: Engineering Experiment Station. Bulletin Series, No. 368: The Effect of Eccentric Loading, Protective Shells, Slenderness Ratios and other Variablesin Reinforced Concrete Columns. By Prof. Frank E. Richart, Prof. Jasper O. Draffin, Tilford A. Olson and Richard $\mathbf{H}$. Heitman. Pp. 128. 1 dollar. Bulletin Series, No. 365 : Experience in Illinois with Joints in Concrete Pavements. By Prof. John S. Crandell, Vernon L. Glover, Whitney C. Huntington, J. Douglas Lindsay, Prof. Frank E. Richart and Prof. Carroll C. Wiley. Pp. 258. 1 dollar. (Ürbana, Ill. : University of Illinois Engineering Experiment Station, 1947.)

Fonds National de la Recherche scientiflque. Vingtième Rapport Fonds National de la Recherche scientifique. Vingtieme Rapport Recherche scientiflque, 1947.)
[65 